
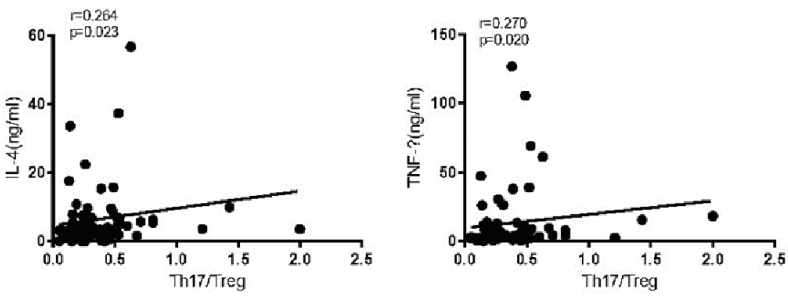

Figure 2. Correlation of the serum levels of IL-4 and TNF- $\alpha$ with the ratio of Th17/Treg.

Disclosure of Interests: None declared

DOI: 10.1136/annrheumdis-2019-eular.4762

\section{AB0074 INTERRELATIONSHIP BETWEEN NICOTINIC ACETYLCHOLINE RECEPTOR AND CYTOKINE PRODUCTION NOTED FOLLOWING T-CELL ANTIGEN RECOGNITION AND ACTIVATION}

Nicholas Manolios ${ }^{1,2,3}$, Kevin Hou ${ }^{4}$, Han-Shen Tae ${ }^{5}$, David Adams ${ }^{6} .{ }^{1}$ University Sydney/Westmead Hospital, Rheumatology, Sydney, Australia; ${ }^{2}$ The University of Sydney, Rheumatology, Camperdown, Australia; ${ }^{3}$ Westmead, Rheumatology, Westmead, Australia; ${ }^{4}$ Westmead, Rheumatology, Westmead, Sydney, Australia; ${ }^{5}$ University of Wollongong, Wollongong, Australia; ' ${ }^{6}$ niversity of Wollongong, Illawarra Health and Medical Research Institute, Wollongong, Australia

Background: $T$ cells express muscarinic and nicotinic acetylcholine receptors (mAChRs, nAChRs) that increase intracellular $\mathrm{Ca}^{2+}$ [1] on stimulation. The expression of these receptors on macrophages and their activation by vagal stimulation has recently been the focus for novel arthritis treatment [2].

Objectives: Our aim in the present study was to assess the effect of various peptides, on cytokine production and nAChRs inhibition.

Methods: nAChR heterologous subunits were expressed in Xenopus oocytes and the inhibitory activity of various peptides at ACh-evoked currents were assessed. The effect of these peptides on T-cell antigen recognition and subsequent cytokine production was assessed using an antigen presentation assay (APA). Briefly, the 2B4.11 murine T cell hybridoma recognizing cytochrome $\mathrm{c}$ as the antigen was co-cultured with the antigen presenting $B$ cell hybridoma line LK35.2 (I-Ek bearing) and pigeon cytochrome $c$ in the absence or presence of peptide or several nAChRs antagonists, including mecamylamine (broad nAChR antagonist), waglerin-1 ( $\alpha 1 \beta 1 \varepsilon \delta)$, $\alpha$-bungarotoxin ( $\alpha 7)$, RgIA ( $\alpha 9 \alpha 10)$, Vc1.1 ( $\alpha 9 \alpha 10)$ and dihydro- $\beta$-erythroidine hydrobromide ( $\alpha 4 \beta 4$ and $\alpha 4 \beta 2)$. ELISA and real-time PCR were performed to measure cytokine protein levels and nAChRs Tcells mRNA express levels separately.

Results: At $10 \mu \mathrm{M}$, peptide W32052 had modest $50-55 \%$ inhibition of human (h)

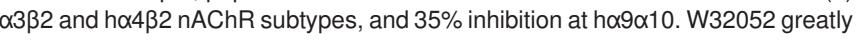
inhibited chimeric rat $\alpha 1 \beta 1 \delta$-mouse $\varepsilon(85 \%)$ at $10 \mu \mathrm{M}$. W32052 also inhibited IL-2, IL-6, TNF- $\alpha$ and GM-CSF production at $50 \mu \mathrm{M}$ in the APA. nAChRs antagonists, mecamylamine $(100 \mu \mathrm{M}), \mathrm{RgIA}(10 \mathrm{nM}), \mathrm{V}_{\mathrm{c}} 1.1(17.5 \mu \mathrm{M})$ and dihydro- $\beta$-erythroidine hydrobromide $(10 \mu \mathrm{M})$ could decrease IL-2 production. However, waglerin-1 and $\alpha$-bungarotoxin did not affect IL-2 production in the APA.

Conclusion: W32052, an antagonist of nAChR, inhibits cytokine production following antigen recognition suggesting that there is a close link between T-cell antigen activation, ion channel regulation mediated by $\mathrm{AChR}$ and cytokine production. Further experiments are in progress.

\section{REFERENCES}

[1] Masato M, Yukari I, Takeshi FJ, et al. Acetylcholine released from T cells regulates intracellular $\mathrm{Ca} 2+$, IL-2 secretion and $\mathrm{T}$ cell proliferation through nicotinic acetylcholine receptor, Life Science, 2017, 172: 13-18.

[2] Koopman FA, Chavan SS, Tak PP, et al. Vagus nerve stimulation inhibits cytokine production and attenuates disease severity in rheumatoid arthritis, PNAS, 2016, 113(29):8248-9.

Disclosure of Interests: None declared

DOI: 10.1136/annrheumdis-2019-eular.3856

\section{AB0075 EFFECT OF SIDAGURI EXTRACT (SIDA RHOMBIFOLIA L) ON URINARY CARBOXY-TERMINAL TELEPEPTIDES OF TYPE II COLLAGEN IN OSTEOARTHRITIC PATIENTS}

Blondina Marpaung ${ }^{1}$, Sheena Dalimunthe ${ }^{2}$, Joshua Patrick², William Simanjuntak². ${ }^{1}$ Universitas Sumatera Utara, Division of Rheumatology, Internal Medicine, Medan, Indonesia; ${ }^{1}$ Universitas Sumatera Utara, Division of Rheumatology, Internal Medicine, Medan, Indonesia

Background: Osteoarthritis is one of the most common joint diseases in Indonesia and elsewhere. Assessment of the effectiveness of osteoarthritis therapy with biomarkers should be developed. One of the biomarker that can be used to assess the activity of osteoarthritis is Urinary Carboxy-Terminal Telepeptides of Type /I Collagen. Indonesia is the center of world biodiversity, and Sidaguri is one of the traditional plants that is believed to have many benefits including its antiinflammatory effect and the ability to decrease level of uric acid. The $\beta$-sitosterol is an active component in Sidaguri that has anti-inflammatory activity in osteoarthritis

Objectives: To compare the effect of sidaguri and meloxicam therapy with meloxicam alone in decreasing the levels of urinary Carboxy-Terminal Telepeptides Of Type II Collagen in osteoarthritis patients.

Methods: This study was conducted on 24 patients with osteoarthritis at $\mathrm{H}$. Adam Malik General Hospital Medan from April to June 2018. Subjects were divided into 2 groups, namely placebo and Sidaguri group. Levels of UCTX II were assessed before and after intervention. T- test was used to analyze the data using SPSS version 22.

Results: $83.3 \%$ of osteoarthritis patients in $\mathrm{H}$. Adam Malik hospital who participated in this study were women with mean age $60.58 \pm 9.74$ years in the placebo group and $63.08 \pm 6.14$ years in the sidaguri group. The results showed that subjects receiving Sidaguri showed significant decrease in uCTX II before and after intervention ( $521.42 \pm 369.99$ vs $330.75 \pm 163.49 \mathrm{ng} / \mathrm{mmol}, \mathrm{p}=0.033$ ). Meanwhile, in the placebo group also found decreased levels of UCTX II but it was not statistically significant $(286.17 \pm 163.82$ vs. $218.25 \pm 75.05 \mathrm{ng} / \mathrm{mmol}, \mathrm{p}=0.238$ ) In addition, there was a significant difference between the mean of the two groups after the intervention $(p=0.046)$.

Conclusion: There was a significant decrease in UCTX II levels in osteoarthritis patients who received Sidaguri extract for 30 days compared to the placebo group.

\section{REFERENCES}

[1] Aigner, T, et al. 2015. Pathogenesis and Pathology of Osteoarthritis. In Hochberg. M, Silman. A, Smolen. J, Weinblat. M, Weisman. M, editors. Rheumatology. 6th ed. Philadelphia : Elsevier; p. 1462-1476.

[2] Alpiansyah, A. 2015. Antihyperuricemia Potential of Sida rhombifolia L. as a Treatment for Gout. Journal Majority. Vol. 4 (3):9-13.

[3] Davies NM., Skjodt NM,. 1999. Clinical Pharmakinetics of Meloxicam. Clin Pharmacokinet Feb;36(2):115-126.

[4] Gupta MB, et al. 1980. Anti-inflammatory and antipyretic activities of betasitosterol. Planta Med. 1980 Jun;39(2):157-63

[5] Marpaung, B. 2010. Penggunaan Petanda Biokimia Asam Hialuronat Serum Dan CTX-II Urin Terhadap Penilaian Hasil Pengobatan Osteoartritis Lutut. Medan : University of Sumatera Utara Institutional Repository

Disclosure of Interests: None declared

DOI: 10.1136/annrheumdis-2019-eular.3977

\section{AB0076 CAN DIFFERENT INTERLEUKIN LEVELS PREDICT RESPONSE TO BIOLOGICAL TREATMENT IN PATIENTS WITH RHEUMATOID ARTHRITIS?}

Stephen McDonald ${ }^{1,2}$, Rachel Reed ${ }^{3,4}$, Ivona Baricevic-Jones ${ }^{4}$, Stephanie Ling ${ }^{1,5}$, Darren Plant ${ }^{5}$, Anne Barton ${ }^{5}$. ${ }^{1}$ University of Manchester, NIHR Manchester BRC, Manchester, United Kingdom; ${ }^{2}$ Manchester University Foundation Trust, The Kellgren Centre, Manchester, United Kingdom; ${ }^{3}$ University of Manchester, Manchester Molecular Pathology Innovation Centre, Manchester, United Kingdom; ${ }^{4}$ University of Manchester, Stoller Biomarker Discovery Centre, Manchester, United Kingdom; ${ }^{5}$ University of Manchester, Division of Musculoskeletal and Dermatological Sciences Centre for Genetics and Genomics, Centre for Musculoskeletal Research, Manchester, United Kingdom

Background: The cytokine family interleukin IL-17 has an important pro-inflammatory role; stimulating tumour necrosis factor (TNF), interleukin IL-1 and IL-6 production. It is subclassified into IL-17A, IL-17F and IL-17AF ${ }^{1}$. The interleukin IL10 acts by blocking the secretion of pro-inflammatory cytokines ${ }^{2}$. We hypothesised that patients whose disease activity is not adequately controlled by TNF therapies in Rheumatoid Arthritis (RA) may have IL-17 driven disease and that lower IL-10 levels may play a permissive role.

Objectives: To determine if pre-treatment or 3 month IL-17/IL-10 concentrations correlate with treatment response to anti-TNF drugs by 6 months of treatment. Methods: Data was collected from the Biologics in Rheumatoid Arthritis Genetics and Genomics Study Syndicate (BRAGGSS). Patients were followed up at pretreatment (baseline), 3 months, 6 months and 12 months with bloods, questionnaires and clinical data obtained. Patients were eligible for inclusion if commencing on adalimumab or etanercept and were designated good or poor EULAR responder status at 6 -months. Wilcoxon rank sum compared interleukin levels at pre-treatment and 3 months- according to EULAR classification by 6 months. Logistic regression was carried out adjusting for gender, baseline DMARD use and disease activity scores (DAS-28). 
Results: 152 patients were included, (80 adalimumab-treated and 72 etanercepttreated). No statistically significant difference between mean IL-17A, IL-17AF, IL$17 \mathrm{~F}$ and IL-10 levels at baseline and 3 month follow-up were observed(figure 1) For IL-17A, those patients classified as good responders demonstrated an increase in mean serum levels of IL-17A from $1.06 \mathrm{pg} / \mathrm{ml}$ at baseline to $1.23 \mathrm{pg} / \mathrm{ml}$ at 3 months. This came close to significance $(p=0.07)$. Further analysis was carried out by drug group and also a subgroup analysis by drug group linked to responder status. No statistically significant results were obtained. Adjusting for gender, baseline DMARD use and DAS-28 scores did not alter findings.

\begin{tabular}{|c|c|c|c|c|c|c|}
\hline$\frac{\text { Interleukin levels }}{(\mathrm{pg} / \mathrm{ml})}$ & $\frac{\stackrel{\text { All }}{\text { Patients }}}{(n=152)}$ & $\begin{array}{l}\underline{P-} \\
\text { values }\end{array}$ & $\frac{\begin{array}{c}\text { Good } \\
\text { Responders }\end{array}}{(n=86)}$ & $\begin{array}{l}\text { P- } \\
\text { values }\end{array}$ & $\begin{array}{c}\begin{array}{c}\text { Poor } \\
\text { Responders }\end{array} \\
(n=66)\end{array}$ & $\begin{array}{c}P=- \\
\text { values }\end{array}$ \\
\hline Baseline IL-17A & 1.16 & - & 1.06 & - & 1.29 & - \\
\hline 3 month IL-17A & 1.21 & $\begin{array}{c}(p= \\
0.76)\end{array}$ & 1.23 & $\begin{array}{c}(p= \\
0.07)\end{array}$ & 1.19 & $\begin{array}{l}(p= \\
0.49)\end{array}$ \\
\hline Baseline IL-17AF & 21.51 & - & 16.40 & - & 28.32 & - \\
\hline 3 month IL-17AF & 30.98 & $\begin{array}{l}(p= \\
0.57)\end{array}$ & 21.89 & $\begin{array}{l}(p= \\
0.58)\end{array}$ & 42.43 & $(p=0.81)$ \\
\hline Baseline IL-17F & 1.97 & - & 2.50 & - & 1.28 & - \\
\hline 3 month IL-17F & 1.59 & $\begin{array}{l}(p= \\
0.66)\end{array}$ & 1.41 & $\begin{array}{l}(p= \\
0.89)\end{array}$ & 1.81 & $(p=0.42)$ \\
\hline Baseline IL-10 & 9.26 & - & 8.41 & - & 10.38 & - \\
\hline 3 month IL10 & 10.52 & $\begin{array}{l}(p= \\
0.93)\end{array}$ & 11.49 & $\begin{array}{l}(p= \\
0.59)\end{array}$ & 9.33 & $(p 0.42)$ \\
\hline
\end{tabular}

Figure 1. Mean interleukin levels at pre-treatment and 3 months

Conclusion: There was a lack of statistically significant data to suggestion a correlation between pre-treatment and 3 month IL-17F, IL-17AF and IL-10 concentrations. However, an increase in IL17-A serum levels between baseline and 3 months may be associated with a good EULAR response status by 6 months. Larger sample sizes are required to confirm this.

\section{REFERENCES}

[1] Gaffen SL. Curr Rheumatol Rep 2009; 11(5): 365-370.

[2] Alanara T. Scand J of Rheumatol 2010; 39: 118-126

Disclosure of Interests: None declared

DOI: 10.1136/annrheumdis-2019-eular.345

\section{AB0077 SERUM IL17 CORRELATED WITH INFLAMMATORY CHANGES BUT NOT WITH BONY CHANGES IN BOTH HAND OSTEOARTHRITIS AND RHEUMATOID ARTHRITIS}

Amany Ebaid ${ }^{1}$, Mohammed A. Mortada ${ }^{1}$, Essam Atwa ${ }^{1}$, Noha M. Hammad ${ }^{2}$ ${ }^{1}$ Faculty of Medicine. Zagazig University, Rheumatology and Rehabilitation, Zagazig, Egypt, ${ }^{2}$ Faculty of Medicine. Zagazig University, medical microbiology and immunology, Zagazig, Egypt

Background: previous studies showed that serum IL17 is correlated with disease activity in both osteoarthritis and rheumatoid arthritis which may have therapeutic reflections $(1,2)$. Taking in consideration that $O A$ has different pathogenesis and presentations in comparison with RA; it is not known what the source of high serum level of IL17 in both diseases is?

Objectives: To evaluate the association of IL17 serum level with musculoskeletal ultrasound (MSK US) findings and clinical disease activity in Rheumatoid Arthritis (RA) and hand Osteoarthritis (OA) patients.

Methods: It is a randomized controlled clinical trial, which was done in the period between June 2017 and June 2018. The total number of the included subjects was 120 in 3 equal groups (RA, OA and control). All subject was subjected to serum IL17 level measurement. MSK US (of both wrists, MCPs, PIPs and DIPS) was done to all patients in RA and OA groups to. Disease activity was measured by disease activity score (DAS28) for RA patients. Visual analogue scale for pain (VAS) was obtained from patients in RA and OA groups. Functional assessment was done using health assessment questionnaire (HAQ) for RA patients and the Australian/Canadian (AUSCAN) Osteoarthritis Hand Index for OA patients

Results: Serum levels of IL17 were significantly higher $(p<0.0001)$ in both RA group and OA (141.37 \pm 51.09 and $151.69 \pm 23.13)$ group in comparison to control group (32.46 \pm 20.71$)$

The serum level of IL17 was correlated with disease activity parameters (DAS28 \& VAS for RA and VAS for OA) both RA and OA groups. As regards ultrasonographic findings, serum IL17 levels were correlated with the presence of synovitis in both RA and OA groups. Ultrasonographic detected bony changes (erosions and osteophytes) were not correlated with serum level of IL17 in neither RA nor OA group. As regards functional assessment, serum level of IL17 was correlated with HAQ in RA group but not correlated with AUSCAN in OA group.
Conclusion: Serum level of IL17 was correlated with inflammatory changes detected by US and not correlated with bonny changes (erosions and osteophytes). According to the results of this study, the inflammatory process is the source of increased level of IL17in OA and RA.

\section{REFERENCES}

[1] PLoS One. 2017; 12(6): e0178879.

[2] Ther Adv Musculoskelet Dis. 2013 Apr; 5(2): 77-94.

Disclosure of Interests: None declared

DOI: 10.1136/annrheumdis-2019-eular.2253

\section{$\mathrm{AB} 0078$ \\ THE THERAPEUTIC EFFECT OF GPNMB IN A TRAUMATICALLY-INDUCED OSTEOARTHRITIC MODEL}

Bryson Cook ${ }^{1}$, Asaad Al Adlaan ${ }^{1}$, Mathew Desanto ${ }^{1}$, Rama Safadi ${ }^{1}$, Salvatore Frangiamore ${ }^{2}$, Fayez Safadi ${ }^{1,3} .{ }^{1}$ Rootstown, Anatomy and Neurobiology, Musculoskeletal Research Group, Rootstown, United States of America; ${ }^{2}$ Akron, Orthopaedics, Akron, United States of America; ${ }^{3}$ Akron Children's Hospital, Rebecca D Considine Research Institute, Akron, United States of America

Background: Osteoarthritis is a severe joint disease that affects millions of people. At this time, the current treatment for osteoarthritis is total joint reconstruction surgery. GPNMB plays a key role in bone remodeling and bone growth. Data from our lab suggested that GPNMB is positive regulator of osteoblastogenesis and a negative regulator of osteoclastogenesis.

Objectives: The role of GPNMB in cartilage has not been investigated before. In this study we examined the therepaeutic effects of GPNMB on damaged cartilage using post-traumatic osteoarthritic mouse model.

Methods: The destabilization of the medial meniscus (DMM) surgery in mice has been found to be an excellent model for studying post-traumatic osteoarthritis. We performed the DMM surgery on 21 C57/BL6 mice. These mice were divided into three intra-articular injection treatment groups consisting of a control, low dose GPNMB, and high dose GPNMB. These mice were divided into three intra-articular injection treatment groups consisting of a control, low dose GPNMB, and high dose GPNMB. Moderate to severe osteoarthritis develops around six to eight weeks with this model.

Results: Here we present that damaged human cartilage has significantly higher levels of GPNMB compared to undamaged cartilage. In addition, human osteoarthritic chondrocytes treated with GPNMB showed a protective response to inflammation induced by IL1-beta. In this study, we examined whether recombinant GPNMB has an anti-inflammatory effect in a model of post-traumatic osteoarthritis. Based on studies performed in our lab, we expected cartilage degeneration to be dramatically decreased in response to the therapeutic effects of GPNMB. A protective factor against osteoarthritis progression, GPNMB-injected mice had significantly reduced cartilage damage and OARSI scores in comparison to the control group, proving GPNMB a promising therapy in lieu of total joint reconstruction. GPNMB-injected mice also had reduced expression of IL-6 and MMP13 but significantly increased expression of aggrecan in comparison to control mice.

Conclusion: Our data clearly showed that GPNMB has therapeutics anti-inflammatory effects on protecting cartilage damaged. Hence, future studies will be directed towards examining the therapeutic effects of GPNMB on larger animal models for osteoarthritis. Given the remarkable ability of GPNMB to reduce expression of key inflammatory markers, we conducted this study to reveal GPNMB therapeutic effects in traumatically-induced osteoarthritis.

\section{REFERENCES}

[1] The surgical destabilization of the medial meniscus (DMM) model of osteoarthritis in the 129/SvEv mouse. Methods in Molecular Biology: Osteoporosis and Osteoarthritis. Loeser RF, Goldring SR, Scanzello CR, Goldring MB. Osteoarthritis: A disease of the joint as an organ. Arthritis and Rheumatism. 2012. pp. 1697-1707.

[2] Zhou, L., Zhuo, H., Ouyang, H., Liu, Y., Yuan, F., Sun, L.,. ... \& Liu, H. (2017). Glycoprotein non-metastatic melanoma protein b (Gpnmb) is highly expressed in macrophages of acute injured kidney and promotes M2 macrophages polarization. Cellular immunology, 316, 53-60.

[3] Ripoll, V.M., et al., Gpnmb is induced in macrophages by IFN-gamma and lipopolysaccharide and acts as a feedback regulator of proinflammatory responses. J Immunol, 2007. 178(10): p. 655766.

[4] Karlsson C, Dehne T, Lindahl A, Brittberg M, Pruss A, Sittinger M, Ringe J. Genome-wide expression profiling reveals new candidate genes associated with osteoarthritis. Osteoarthritis and Cartilage. 2010 Apr 1;18(4):58192.

Disclosure of Interests: None declared DOI: 10.1136/annrheumdis-2019-eular.6561 